\title{
PENGEMBANGAN DESAIN BATIK MAKASSAR DENGAN SUMBER IDE KAPAL PINISI
}

\author{
Anadia Natasyah Utami ${ }^{1}$ (anadtasyautami@gmail.com, Prodi Kriya Tekstil, FSRD, Universitas Sebelas Maret) \\ Setyawan² (setyawan@staff.uns.ac.id, Prodi Kriya Tekstil, FSRD, Universitas Sebelas Maret) \\ Felix Ari Dartono 3 (felixari@staff.uns.ac.id, Prodi Kriya Tekstil, FSRD, Universitas Sebelas Maret)
}

\begin{abstract}
The purpose of this creative process was to enrich Batik Makassar which focused on visualizing motifs by using the potential of Buginesse-Makassar heritage, the Pinisi Sailing Boat combined with Lontara writings from Makassar as a source of inspiration for Batik designs differentiation. The visual method is designed by considering its aesthetic value as a renewal products from the existing potential of Batik Makassar. The creative process with this design method produces six designs and three of those were painted on $230 \mathrm{~cm} \times 110 \mathrm{~cm}$ nonwoven silk fabric.
\end{abstract}

Keywords: development, design, batik Makassar, Pinisi ailing boat, lontara

\section{ABSTRAK}

Tujuan proses kreatif ini adalah mengembangkan desain Batik Makassar yang berfokus pada pengolahan visual (motif) dengan memanfaatkan potensi warisan budaya Bugis-Makassar yaitu Kapal Pinisi yang dipadukan dengan aksara Lontara Batik Makassar sebagai sumber ide pengembangan desain batik. Pengolahan visual dirancang dengan mempertimbangkan nilai estetis sebagai potensi pembaharuan batik Makassar yang sudah ada. Proses kreatif dengan metode desain ini menghasilkan enam desain dan tiga di antaranya direalisasi pada kain sutera ATBM yang berukuran $230 \mathrm{~cm} \times 110$ $\mathrm{cm}$.

Kata Kunci: pengembangan, desain, batik Makassar, Kapal Pinisi, lontara

\section{PENDAHULUAN}

Sejak dahulu, suku Bugis-Makassar terkenal sebagai pelaut ulung, tangkas, dan tahan uji. Orang-orang Makassar pada masa itu amat berani berlayar mengarungi lautan luas, sehingga orang Portugis menjuluki mereka Celebes de Makassares, yang berarti orang-orang Makassar yang ulung dan mahsyur. Berlayar menggunakan kapal dan merantau merupakan kebiasaan turuntemurun masyarakat Makassar. Kapal yang digunakan untuk merantau adalah Kapal
Pinisi. Pinisi adalah kapal layar tradisional khas suku Bugis-Makassar. Kapal ini memiliki dua tiang layar utama dengan tujuh layar, yaitu ada tiga layar di ujung depan, dua di tengah, dan dua di belakang. Keterkaitan antara suku Bugis-Makassar dengan Kapal Pinisi, menjadikan Kapal Pinisi sebagai lambang kota Makassar. Keunikan bentuk serta pengetahuan tentang teknologi pembuatan kapal dengan rumus dan pola penyusunan lambung kapal membuat Kapal Pinisi 
ditetapkan sebagai warisan budaya tak benda oleh UNESCO sejak 7 Desember 2017.

Demikian halnya dengan batik, UNESCO telah menetapkan batik sebagai warisan budaya dunia yang dihasilkan oleh Bangsa Indonesia pada tahun 2009. Hal ini menyebabkan semakin giatnya pengembangan desain motif batik di daerah. Daerah-daerah yang mengembangkan batik pada umumnya menonjolkan ciri khas daerahnya untuk dijadikan motif khas daerah tersebut, sehingga Batik Makassar mulai berkembang di kota Makassar. Hal ini dibuktikan dengan produksi batik dan penjualan batik khas Makassar di Sulawesi Selatan. Awal munculnya Batik Makassar didasari oleh keinginan melestarikan budaya aksara lontara dalam sebuah media baru, yakni melalui batik (Jeanni, 2016, dalam wawancara pada 14 November 2016). Sebagian besar batik yang diperjualbelikan di Makassar menggunakan aksara Iontara sebagai motif utama. Pengaplikasian lontara pada batik dianggap masih tergolong sederhana dan kurang bervariasi. Motif aksara lontara masih sulit untuk digayakan karena aksara lontara memiliki aturan dan ketentuan dalam penulisannya. Perubahan bentuk dasar aksara lontara dapat menimbulkan makna lain dan mengaburkan makna aslinya. Batik Makassar hanya menggunakan motif aksara lontara tanpa adanya motif tambahan.

Hal tersebut memicu penulis untuk mengembangkan desain batik Makassar agar lebih bervariasi dari segi visual motif khas daerahnya. Peluang untuk mengembangkan desain batik Makassar masih terbuka lebar karena desain motif yang ada di pasar masih kaku dan butuh pengembangan agar lebih bervariasi dan menarik. Batik Makassar yang sekarang berada di pasaran masih belum memikirkan efek visual yang tercipta dari teknik pengulangan yang ada. Motif batik yang ada di Makassar sejauh ini adalah motif yang mengolah visual aksara lontara, sehingga perlu adanya pengembangan desain batik Makassar terutama dari segi visual dengan pertimbangan perancangan batik yang benar, seperti memikirkan efek visual yang tercipta dari teknik pengulangan serta mengolah visual dari kebudayaan Bugis-Makassar. Pengembangan desain Batik Makassar yang ditawarkan pada perancangan ini memvisualisasikan kebudayaan BugisMakassar dengan paduan motif Kapal Pinisi dan lontara yang diaplikasikan di atas kain sutera ATBM Sengkang.

Penulisan ini mengkaji tentang proses kreatif pengembangan desain batik Makassar. Ada beberapa permasalahan yang perlu dikaji dalam mengembangkan desain batik Makassar dengan sumber ide Kapal Pinisi. Pertama, permasalahan visual yaitu bagaimana mentransformasikan visual Kapal Pinisi (tiga dimensi) sebagai motif utama serta mentransformasikan visual gelombang air laut dan aksara lontara sebagai motif pendukung ke media kain (dua dimensi) dengan menggunakan teknik batik. Beberapa aspek seperti aspek estetis, aspek teknik, dan aspek bahan perlu diperhatikan untuk mempertahankan karakter visual Kapal Pinisi tanpa mengabaikan ciri khas dari batik Makassar. Kedua, masalah desain visual yaitu bagaimana mewujudkan desain batik dengan mengolah visual Kapal Pinisi agar tetap mempertahankan keunikan dan ciri khas Makassar. Ketiga, permasalahan teknis untuk mewujudkan desain menjadi kain batik.

\section{Pengembangan Motif Batik di Daerah}

Industri batik di Indonesia secara tidak langsung telah muncul sejak adanya tradisi membatik di Nusantara. Pengukuhan PBB yang menyatakan bahwa batik adalah warisan budaya dunia asli dari Indonesia, memunculkan semangat baru untuk melestarikan dan mengembangkan batik 
(Wulandari, 2011: 158). Batik tidak lagi sekedar masalah produk tradisi dalam arti sempit, namun batik juga menyangkut permasalahan menciptakan berbagai peluang pengembangan gagasan, nilai, identitas, praktik, arah perubahan sosial, iptek, dan media-media baru (Pambudy, 2000 : 236). Perkembangan batik di Indonesia tidak hanya di pulau Jawa, menurut hasil survei, tahun 2009 industri batik meluas hingga seluruh Indonesia.

Pengembangan motif batik di seluruh Indonesia membuat tiap daerah memunculkan ciri khas daerahnya untuk dijadikan motif batik. Batik yang terinspirasi dari ciri khas suatu daerah memiliki keunikan dari sisi identitas batik itu sendiri, sehingga dapat mengingatkan seseorang akan daerah tersebut. Hal ini menimbulkan motif-motif baru yang semakin beragam dan menarik. Ada beberapa daerah di Indonesia yang masih menggali potensi motif batik daerahnya (Marzuqi, 2015: 1). Salah satu daerah yang masih dalam tahap menggali potensi untuk penciptaan desain motif batik yang melambangkan ciri khas daerahnya adalah kota Makassar.

\section{Batik Makassar}

Batik Makassar merupakan batik yang dikembangkan di daerah Makassar. Sejauh ini masyarakat Makassar lebih dikenal sebagai batik Lontara untuk menyebut batik khas Makassar. Batik Lontara sendiri merupakan jenis batik Bugis-Makassar khas Sulawesi Selatan yang memiliki motif aksara lontara. Aksara atau huruf lontara sendiri merupakan aksara tradisional masyarakat BugisMakassar. Bentuknya yang unik menjadikan motif batik Lontara sangat unik dan indah. Motif ini juga dianggap mewakili empat etnis di Sulawesi, seperti Bugis, Makassar, Toraja, dan Mandar, yang semuanya menggunakan aksara tersebut (Erick dalam www.artikel-
Indonesia.com). Sejauh ini, ada dua motif khas yang ditemukan, yakni motif Lontara (aksara tradisional masyarakat Bugis-Makassar) dan alat-alat kesenian tradisional (Aulia dan Harahap dalam www.nasional.kompas.com).

\section{Lontara}

Bahasa daerah masyarakat Makassar adalah bahasa Makassar (Bugis). Bahasa daerah ini memiliki aksara yang dapat merekam atau mencatat nilai-nilai luhur (indigeneous knowledge) yang disebut pasang 'pesan-pesan' dalam adat istiadat (Paeni, 2003: 3). Aksara tersebut dikenal sebagai aksara lontara. Menurut sejarahnya, aksara lontara berasal dari nama jenis pohon lontara (pohon lontar). Orang-orang Bugis-Makassar menjadikan lontara sebagai alat tulis yaitu tempat mencatatkan semua peristiwaperistiwa dan pandangan-pandangan penting yang pernah dialami dan dikemukakan oleh orang-orang Bugis-Makassar, baik dari pidato, kelong-kelong (puisi atau nyanyian), maupun syair-syair perang pada masa itu (Wahyuni, 2014: 55). Huruf lontara ini pada umumnya dipakai untuk menulis tata aturan pemerintahan dan kemasyarakatan (Wihanry dan Chyan, 2015: 3).

\section{Kapal Pinisi}

Pinisi merupakan seni pembuatan perahu yang dilakukan oleh masyarakat di Sulawesi Selatan. Secara harfiah, "Pinisi" merupakan penamaan untuk tali-temali, tiang, dan layar perahu sekunar Sulawesi, akan tetapi bagi masyarakat Indonesia dan bahkan secara internasional kata itu telah menjadi sebutan populer bagi kebanyakan tipe perahu Nusantara (Liebner, 1996: 37). Seni pembuatan perahu ini merupakan pengetahuan tradisional yang dimiliki oleh masyarakat Bugis-Makassar yang berpusat di Kabupaten Bulukumba, yang terdiri atas tiga desa, yaitu Ara, Tanah Beru, dan Lemo-Lemo 
(Wildan

dalam

www.kebudayaan.kemdikbud.go.id). Menurut sejarah, kapal kayu pinisi telah digunakan di Indonesia sejak beberapa abad yang lalu, diperkirakan Kapal Pinisi sudah ada sebelum tahun 1500-an. Menurut legenda yang berbentuk karya sastra I La Galigo, pada abad ke-14 Pinisi pertama kali dibuat oleh Sawerigading, putra mahkota kerajaan Luwu (Lisbijanto, 2013: 1).

Kapal Pinisi merupakan kapal layar yang terbuat dari bahan kayu yang digerakkan dengan tenaga angin (Prasetyo, 2014: 2). Tiang layar pada Kapal Pinisi yang berjumlah dua buah, membuat Kapal Pinisi dikenal sebagai kapal yang cepat dan memiliki tingkat keseimbangan yang baik. Dua tiang layar penyangga tersebut biasa disebut tiang agung. Kedua tiang agung digunakan untuk membentangkan tujuh buah layar perahu. Tiga buah layar berada di ujung depan, dua layar di bagian depan, dan dua layar lagi terbentang di bagian belakang kapal (Arsa, 2017: 2). Kapal Pinisi memiliki bentuk lambung kapal yang menyerupai serabut kelapa, sehingga jarang terjadi sebuah Kapal Pinisi tenggelam atau terbalik karena kurangnya stabilitas kapal (Jinca dan Raga, 2008: 231). Masyarakat Makassar biasa menggunakan kayu Bitti (vitex cofasus) sebagai bahan utama pembuatan rangka lambung kapal (Dewi, 2016 : 11). Pengetahuan tentang teknologi pembuatan kapal dengan rumus dan pola penyusunan lambung kapal menjadikan Kapal Pinisi sebagai kapal layar tradisional yang mampu berlayar dengan baik dalam jarak penjelajahan yang luas.

\section{Pengembangan Desain}

Potensi-potensi visual dari Kapal Pinisi membuka kemungkinan untuk diadaptasi menjadi motif batik. Pengadaptasian visual ini membuka peluang pengembangan desain.
Desain berasal dari bahasa Inggris Design yang berarti pengubahan makna (melakukan pengubahan makna) yang dilakukan terhadap suatu hal, sedangkan dalam ejaan bahasa Indonesia "desain" secara umum diartikan sebagai potongan, model, moda, bentuk atau pola, konstruksi, rencana, mempunyai maksud, merencanakan, baik, bagus, atau indah bentuknya (Palgunadi, 2007: 2-7). Sedangkan pengembangan merupakan jenis penelitian yang bertujuan untuk menghasilkan produk dengan tujuan tertentu yang diawali analisis kebutuhan kemudian dilanjutkan dengan pengembangan produk, kemudian produk akan dievaluasi (Ratyaningrum dan Novitasari, 2016: 310). Pengembangan desain sangat diperlukan untuk memperbaharui yang telah ada dengan tujuan supaya lebih bervariasi dan memberi gambaran baru sesuai dengan perkembangan zaman (Ratyaningrum dan Novitasari, 2016: 310).

\section{METODE PERANCANGAN}

\section{a. Pendekatan}

Perancangan desain batik Makassar dengan sumber ide visual Kapal Pinisi ini menggunakan pendekatan desain yang terdiri atas: (a) Proses Eksplorasi (exploration process), proses analisis bersifat pendalaman, penelusuran, penggali atas sejumlah hal; (b) Proses Ekstraksi (extraction process), proses analisis yang bersifat rangkuman, ekstraksi dan pembuatan kesimpulan atas sejumlah hal; (c) Titik Terminasi, suatu titik yang mewakili kondisi awal saat akan memulai suatu kegiatan. Bentuk kegiatan pada titik terminasi berupa kegiatan perencanaan kegiatan, evaluasi, melihat kembali, dan presentasi. Tiga tahapan proses desain tersebut kemudian dijabarkan dalam empat langkah operasional, yakni: (a) proses analisis desain dan penetapan target perencanaan; (b) proses analisis aspek desain dan penyusunan 
konsep desain; (c) proses penjabaran konsep dan pembuatan desain (visualisasi); (d) proses tes produk (Palgunadi, 2007:288).

\section{b. Analisis Permasalahan}

Berdasarkan fokus permasalahan di atas ada tiga permasalahan yang muncul dalam mengembangkan desain batik Makassar dengan sumber ide Kapal Pinisi. Pertama, permasalahan visual yaitu bagaimana mentransformasikan visual Kapal Pinisi (tiga dimensi) sebagai motif utama serta mentransformasikan visual gelombang air laut dan aksara lontara sebagai motif pendukung ke media kain (dua dimensi) dengan menggunakan teknik batik. Beberapa aspek, seperti aspek estetis, aspek teknik, dan aspek bahan perlu diperhatikan untuk mempertahankan karakter visual Kapal Pinisi tanpa mengabaikan ciri khas dari batik Makassar. Kedua, masalah desain visual, yaitu bagaimana mewujudkan desain batik dengan mengolah visual Kapal Pinisi agar tetap mempertahankan keunikan dan ciri khas Makassar. Ketiga, permasalahan teknis untuk mewujudkan desain menjadi kain batik.

\section{c. Strategi Pemecahan Masalah}

Mengacu pada analisis permasalahan di atas, yang menjadi permasalahan pokok adalah permasalahan visual. Beberapa strategi dapat dilakukan untuk menyelesaikan permasalahan tersebut. Pertama, mengolah unsur-unsur visual dari Kapal Pinisi menjadi lebih sederhana dengan mempertimbangkan unsur estetis agar tetap mampu mempertahankan karakter Kapal Pinisi tanpa mengabaikan ciri khas dari batik Makassar. Kedua, desain visual dibuat dengan mempertimbangkan teknik batik tulis yang akan dipakai untuk mewujudkan produk yang direncanakan. Ketiga, melakukan studi komparasi produk untuk membandingkan produk yang sejenis, agar desain yang dibuat memiliki nilai kebaruan dan diferensiasi produk serta melakukan wawancara, studi pustaka, dan studi proses produksi untuk memperkuat konsep perancangan dan untuk memperkecil kemungkinan gagal pada saat proses perancangan maupun produksi karya.

\section{PEMBAHASAN}

\section{Hasil Uji Coba Visual dan Teknik}

Dalam perancangan ini diperlukan uji coba visual dan uji coba teknik. Uji coba visual dilakukan untuk mencari karakter Kapal Pinisi yang akan dijadikan motif utama batik. Untuk memberi khas batik, batik diberi isen-isen yang sesuai dengan karakter unsur yang diolah berupa aksara lontara dan gelombang air laut sebagai motif pendukung.
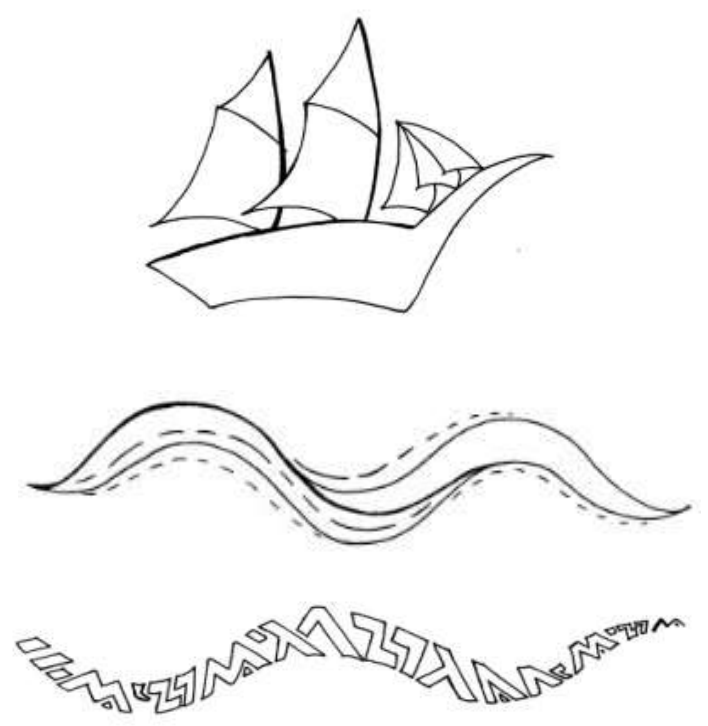

Gambar 1. Pengolahan Visual Kapal Pinisi, Lontara, dan Gelombang air laut

(Sumber: Anadia Natasyah Utami)

Selain itu, penulis melakukan uji coba teknik untuk mengetahui apakah bahan yang digunakan, yaitu sutra ATBM Sengkang dapat diproses dengan teknik batik tulis dan pewarnaan dengan zat pewarna sintetis, remasol. Hasil uji coba teknik yang penulis dapatkan adalah kain sutra ATBM Sengkang yang di batik menggunakan malam dan dapat 
diwarnai oleh zat warna remasol dengan metode teknik colet. Warna yang dihasilkan cukup pekat dan tidak terlalu menurun saat kering.

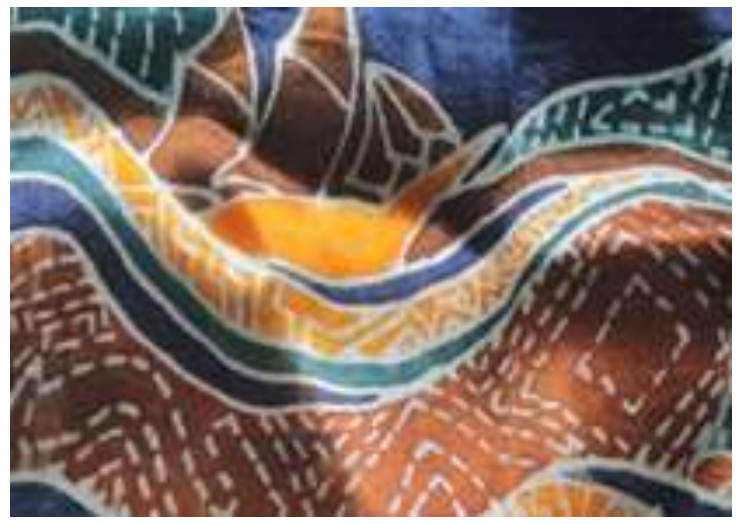

Gambar 2. Hasil Uji Coba Teknik pada Bahan Sutra ATBM Sengkang. (Sumber: Anadia Natasyah Utami)

\section{Konsep Perancangan}

Serangkaian uji coba dan studi telah dilakukan. Dalam visualisasi desain ini lebih ditekankan kepada karakter dan unsur-unsur yang ada pada Kapal Pinsi sebagai motif utama. Untuk memperkuat ciri khas batik Makassar, dilakukan penambahan visual gelombang air laut dan aksara lontara sebagai motif pendukung. Motif pendukung ditambahkan agar visual motif lebih bervariatif. Perancangan visual desain motif batik ini disesuaikan dengan kemampuan perajin batik Makassar yang sejauh ini masih belum memikirkan efek visual yang tercipta. Maka dari itu, Pengembangan desain batik Makassar ini diarahkan menjadi produk massal dengan target pasar pria dan wanita dewasa usia 25-45 tahun.

Penggambaran kebudayaan maritim suku Bugis-Makassar dalam unsur visual Kapal Pinisi dan gelombang air laut yang dipadukan dengan aksara lontara dan isen-isen batik membuat komposisi desain perancangan ini menjadi menarik dan unik. Sedangkan dari segi pewarnaan dibuat lebih beragam dan mengacu pada arahan warna sarung Lipa Sabbe serta tidak terpaku pada warna-warna batik klasik. Kedua hal tersebut dilakukan guna memperkaya pengembangan desain. Untuk proses produksi dilakukan dengan menggunakan teknik batik tulis dengan tujuan mempertahankan kekhasan batik dan menambah nilai dari batik Makassar itu sendiri. Teknik batik tulis dipilih karena goresan-goresan yang dihasilkan lebih luwes (ekspresif) dan tidak akan ada goresan yang sama persis dalam setiap pengulangannya, sehingga dapat memunculkan karakter yang diinginkan.

Hasil dari proses kreatif ini berhasil memvisualisasikan enam desain dan tiga di antaranya diwujudkan pada kain sutra ATBM yang berukuran $230 \mathrm{~cm} \times 110 \mathrm{~cm}$. Koleksi ini mengambil tema "The Macassan" dengan fokus perancangan mengolah visual Kapal Pinisi sebagai sumber ide. Macassan berasal dari kisah pelaut Makassar yang berkelana menggunakan kapal hingga ke Tanah Aborigin, yaitu pantai utara Australia sejak abad ke-18. Pelaut Makassar dikenal sebagai pelaut yang tangguh dan bijaksana. Desain Batik Makassar dengan inspirasi Kapal Pinisi ini dapat diaplikasikan sebagai bahan pakaian untuk pakaian uniseks.

\section{Visualisasi Desain}

Desain pertama ini berjudul "Palambara" (Petualang). Desain ini distrukturkan dari unsur motif Kapal Pinisi dengan motif pendukung gelombang air laut dan aksara lontara. Master desain ini berukuran $21 \mathrm{~cm} \quad x \quad 29,7 \quad \mathrm{~cm}$ dengan pengulangan satu langkah, ke samping, sehingga dapat membentuk kesan dinamis. Desain ini menggunakan teknik batik tulis dan bahan kain sutra ATBM Sengkang. Palambara berarti seseorang yang senang berpetualang, sehingga desain ini menyiratkan makna tentang masyarakat Makassar yang senang berpetualang mengarungi lautan menggunakan Kapal Pinisi. Penggunaan zat warna remasol pada desain ini menghasilkan 
warna orange, coklat, dark cayn, dan biru tua sebagai warna dasar menjadikan desain motif ini terlihat harmonis.

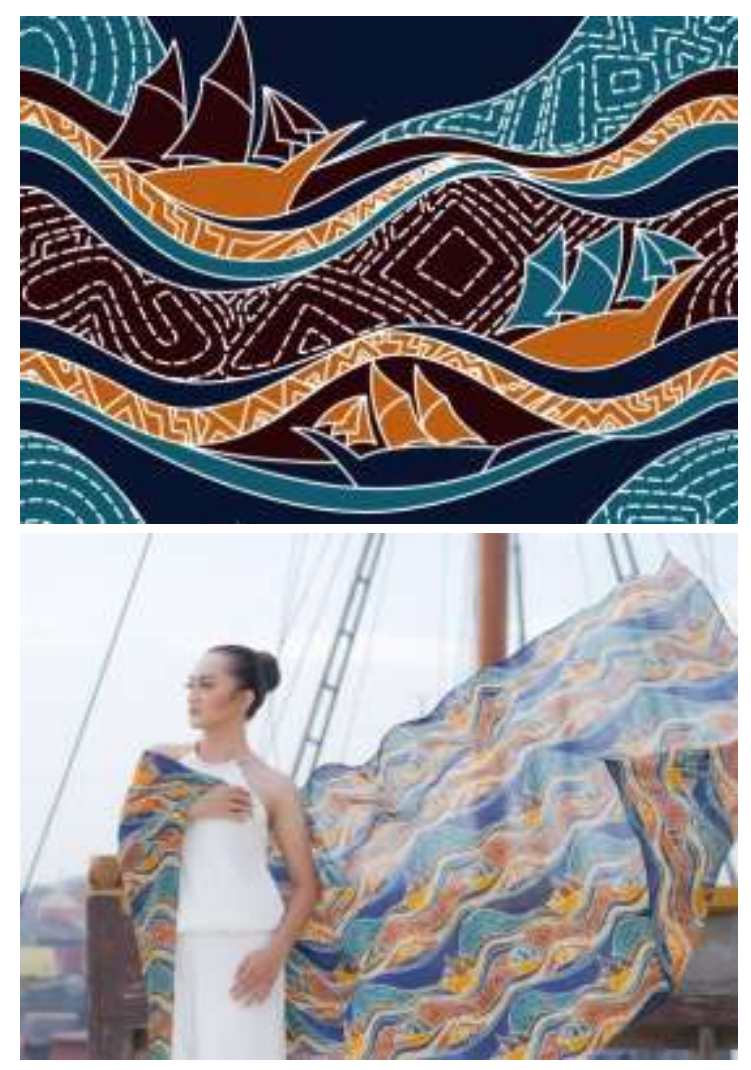

Gambar 3. Master Desain dan Foto Produk "Palambara" (Sumber: Anadia Natasyah Utami)

Desain kedua ini berjudul "Passompe" (Perantau). Desain ini distrukturkan dari unsur motif Kapal Pinisi, dengan motif pendukung gelombang air laut dan aksara lontara. Master desain ini berukuran 29,7 cm x $21 \mathrm{~cm}$ dengan pengulangan setengah langkah ke samping, sehingga dapat membentuk kesan dinamis. Desain ini menggunakan teknik batik tulis dan bahan kain sutra ATBM Sengkang. Pada desain ini terukir visual Kapal Pinisi yang bertuliskan passompe dan gelombang air laut sebagai motif pendukung. Motif ini menunjukan tentang makna dari passompe yang berasal dari kata dasar sompe, yang berarti layar kapal, sehingga pasompe memiliki makna seorang perantau yang berlayar menggunakan kapal layar berupa Pinisi. Dalam pasompe terdapat spirit "sekali layar terkembang, pantang biduk surut ke pantai." Prinsip tersebut membuat perantau Bugis-Makassar dikenal sebagai perantau yang pantang menyerah, karena memiliki prinsip pantang pulang sebelum sukses di tanah rantau. Penggunaan zat warna remasol pada desain ini menghasilkan warna orange, magenta, medium purple, violet, dan indigo sebagai warna dasar.

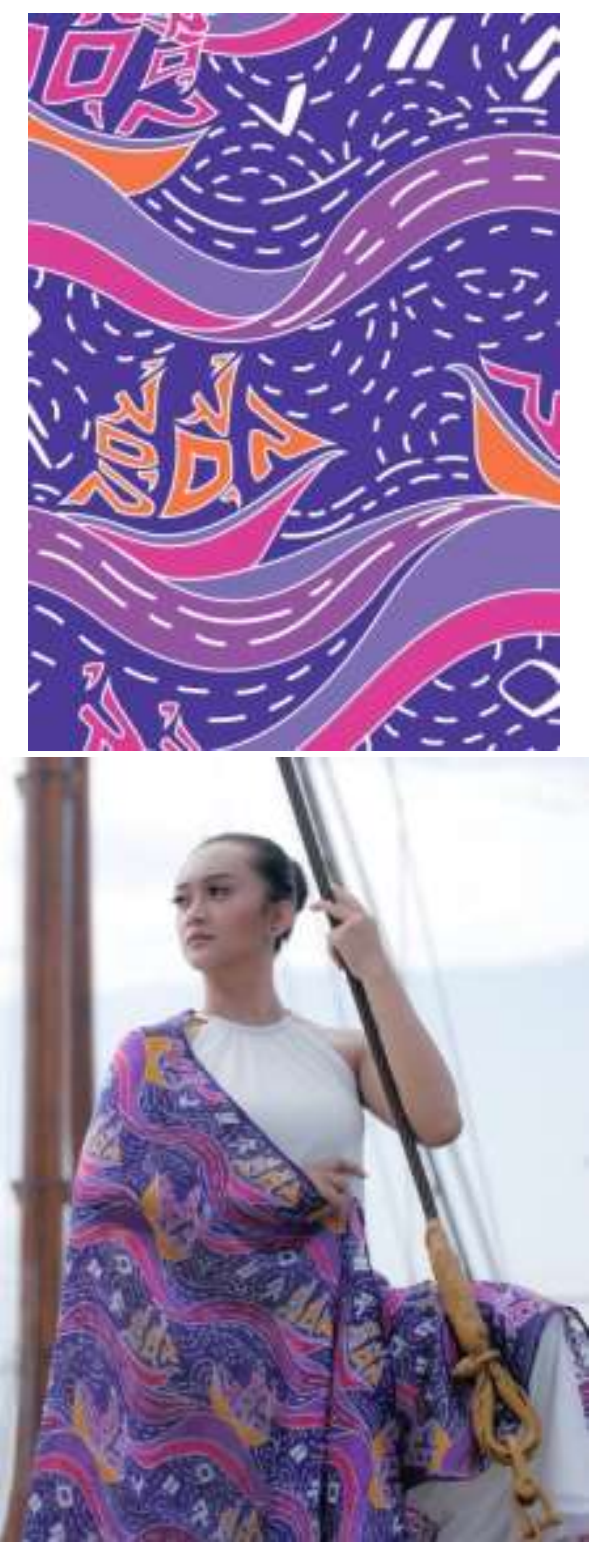

Gambar 4. Master Desain dan Foto Produk "Passompe" (Sumber: Anadia Natasyah Utami)

Desain ketiga ini berjudul "Pasombala" (Pelaut). Desain ini distrukturkan dari unsur motif Kapal Pinisi, dengan motif 
pendukung gelombang air laut dan aksara lontara. Master desain ini berukuran 29,7 cm $x \quad 21 \mathrm{~cm}$ dengan pengulangan setengah langkah ke samping, sehingga dapat membentuk kesan dinamis. Desain ini menggunakan teknik batik tulis dan bahan kain sutra ATBM Sengkang. Desain ini menunjukkan arti dari pasombala, yaitu pelaut. Selain itu pada motif ini terukir aksara lontara yang bertuliskan kualleangi talanga na toalia sebagai salah satu falsafah hidup masyarakat Bugis-Makassar yang memiliki makna 'saya lebih memilih tenggelam dari pada harus kembali tanpa membawa apaapa.' Dapat disimpulkan dari filosofi tersebut mengajarkan nilai perjuangan dan pantang menyerah dalam berusaha. Makna tersebut menjadi dasar sifat pelaut Bugis-Makassar yang tangguh. Penggunaan warna pada desain ini adalah warna kuning, orange, ungu, biru sebagai warna dasar.

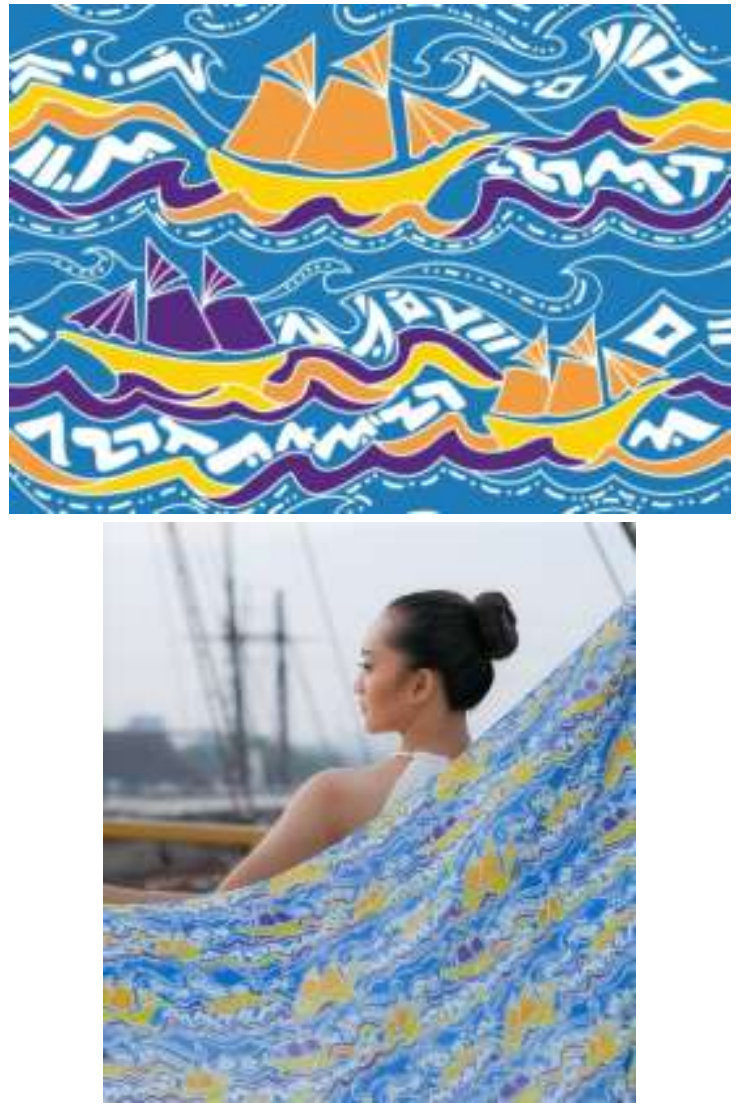

Gambar 5. Master Desain dan Foto Produk "Passompe" (Sumber: Anadia Natasyah Utami)

\section{PENUTUP}

Dalam penulisan ini yang mengkaji tentang proses kreatif pengembangan desain batik Makassar dapat disimpulkan, yaitu Pertama dalam mengembangkan desain batik Makassar dengan sumber ide Kapal Pinisi diperlukan beberapa aspek, seperti aspek estetis, aspek teknik, dan aspek bahan dalam mentransformasikan visual Kapal Pinisi (tiga dimensi) sebagai motif utama serta mentransformasikan visual gelombang air laut dan aksara lontara sebagai motif pendukung ke media kain (dua dimensi) dengan menggunakan teknik batik guna mempertahankan karakter visual Kapal Pinisi tanpa mengabaikan ciri khas dari batik Makassar. Kedua, untuk mewujudkan desain batik Makassar dengan mengolah visual Kapal Pinisi perlu adanya pertimbangan dalam merancang desain visual batik, seperti mempertimbangkan teknik batik tulis yang akan dipakai serta memikirkan efek visual yang tercipta dari teknik pengulangan, sehingga dapat menjadi kekuatan desain yang mempunyai nilai pembeda dibandingkan dengan motif batik Makassar yang sudah ada. Ketiga, melakukan studi komparasi produk untuk membandingkan produk yang sejenis, agar desain yang dibuat memiliki nilai kebaruan dan diferensiasi produk serta melakukan wawancara, studi pustaka, dan studi proses produksi untuk memperkuat konsep perancangan dan untuk memperkecil kemungkinan gagal pada saat proses perancangan maupun produksi karya. Hal-hal tersebut diperlukan agar pengembangan desain batik Makassar yang ditawarkan pada proses kreatif perancangan ini dapat memvisualisasikan kebudayaan BugisMakassar dengan paduan motif Kapal Pinisi dan Lontara yang diaplikasikan di atas kain sutra ATBM Sengkang. 


\section{DAFTAR PUSTAKA}

Arsa, D. 2017. Pinisi Si Kapal Ajaib. Jakarta: Badan Pengembangan dan Pembinaan Bahasa.

Aulia, L. 2012. "Menggali Motif Khas Daerah." SMKN 2 Sungguminasa. dalam https://nasional.kompas.com/read/20 12/06/25/08374358/smkn.2.sunggum inasa.mengqali.motif.khas.daerah.

Diakses 14 Mei 2018.

Dewi, N. 2016. Upacara Pembuatan Perahu Pinisi di Kecamatan Bontohari Kabupaten Bulukumba. Skripsi, Jurusan Sejarah dan Kebudayaan Islam, Fakultas Adab dan Humaniora UIN Alauddin Makassar, Makassar.

Erick. 2015. "Batik Lontara Jadi Kembanggaan Kota Makassar.” dalam http://www.artikelindonesia.com/batik-lontara-jadikembanggan-kota-makassar/. Diakses 14 Mei 2018.

Jinca, M. 2008. "Budaya dan Norma Teknologi Perkapalan Rakyat Tipe Phinisi sebagai Sarana Transportasi dan Wisata Bahari". Vol. 20. No.2.

Liebner, H. 1996. "Beberapa Catatan akan Sejarah Pembuatan Perahu dan Pelayaran Nusantara." Laporan Penelitian, Lembaga Penelitian UNHAS, Ujung Pandang.

Lisbijanto, H. 2013. Kapal Pinisi. Yogyakarta: Graha Ilmu.

Marzuqi, A. 2015. "Penciptaan Motif Batik sebagai Ikon Kabupaten Lumajang." Jurnal ArtNouveau. Vol.4. No.1.
Paeni, M. 2003. Katalog Induk Naskah-Naskah Sulawesi Selatan. Yogyakarta: Gajahmada Universitas Press.

Palgunadi, B. 2007. Desain Produk. Bandung: Institut Teknologi Bandung.

Pambudy, N. 2000. Perjalanan Panjang Batik dalam Seribu Tahun Nusantara. Jakarta: Kompas.

Prasetyo, N. 2014. Kapal Pinisi sebagai Ide Dasar Penciptaan Lampu Duduk, Dinding, dan Gantung dengan Bahan Logam. Tugas Akhir, Universitas Negeri Yogyakarta, Yogyakarta.

Ratyaningrum, F . 2016. “Pengembangan Desain Motif di Usaha Batik "Manggur" Probolinggo." Jurnal Pendidikan Seni Rupa. Vol. 04 No.2.

Wahyuni. 2014. "Sosiologi Bugis Makassar." Skripsi, Program Studi Sosiologi Agama, Fakultas Ushuluddin dan Filsafat Universitas Islam Negeri Alauddin Makassar, Makassar.

Wihanry, I. 2015. "Perancangan Aplikasi Pembelajaran Aksara Lontara dengan Metode Game Based Learning." Jurnal Tematika, Vol.3 No.1.

Wildan, M. 2016. Pinisi. dalam https://kebudayaan.kemdikbud.go.id/ ditwdb/pinisi-2/. Diakses 24 Januari 2018.

Wulandari, A. 2011. Batik Nusantara: Makna Filosofis, Cara Pembuatan, dan Industri Batik. Yogyakarta: CV. Andi Offset (Penerbit Andi). 